\author{
Jakub Polanowski*
}

\title{
CZY SĄDY ADMINISTRACYJNE BĘDĄ ORZEKAĆ MERYTORYCZNIE? UWAGI NA GRUNCIE PREZYDENCKIEGO PROJEKTU USTAWY O ZMIANIE USTAWY - PRAWO O POSTĘPOWANIU PRZED SĄDAMI ADMINISTRACYJNYMI
}

\section{Uwagi wstępne}

Troska o dobro wspólne stanowi podstawę ustroju demokratycznego w Polsce. Konstytucja $R P \mathrm{w}$ art. 1 stanowi, że dobrem wspólnym wszystkich obywateli jest Rzeczpospolita Polska, a troska o to dobro powierzona została jej wszystkim obywatelom. Nieuznawanie tego obowiązku jako prawnie wiążącego stanowi naruszenie norm konstytucyjnych na równi z uchybieniem innym jej przepisom. Co więcej przepis ten zawarty został przez ustrojodawcę w rozdziale I Konstytucji $R P$, który zawiera najistotniejsze zasady ustrojowe. $\mathrm{Z}$ treści przepisów Konstytucji wynika, że stanowi ona najwyższe prawo Rzeczypospolitej Polskiej i winna być stosowana bezpośrednio (art. 8). Oznacza to, że obowiązki w niej wyrażone wiążą w sposób najsilniej określony w polskim prawie. Nie może być mocniejszego zaakcentowania powinności adresatów norm prawnych aniżeli wyrażenie ich w ustawie zasadniczej ${ }^{1}$.

Konstytucja nie wyłącza spośród podmiotów zobowiązanych do stosowania tego obowiązku organów władzy publicznej. Więcej, nakłada ona na wskazane jednostki obowiązek szczególnie pieczołowitej troski o dopełnienie wszelkich obowiązujących je przepisów prawa, w tym przepisów rangi konstytucyjnej. To po pierwsze. Po drugie obliguje je do takiego kształtowania swych działań, by ich podstawą był zawsze wiążący przepis prawa. Zasada ta ma więc podwójny

\footnotetext{
* Dr, Wojewódzki Sąd Administracyjny w Lublinie, Wyższa Szkoła Handlowa w Radomiu.

1 R. Stemplowski (Nasze dobro wspólne, [w:] Ratio est anima legis. Ksiega jubileuszowa ku czci Profesora Janusza Trzcińskiego, Warszawa 2007, s. 103-104) dostrzega, że określonej wizji dobra wspólnego nie można uznać za najwyższe, lecz dobro to należy wciąż na nowo „odkrywać”, poszukując odpowiedzi na pytanie o to, ,,w jakiej mierze nasze dobro wspólne jest wspólne, a obywatel - bliźnim".
} 
wymiar. Z jednej strony organy publiczne mają obowiązek przestrzegania „litery" prawa, to jest spełniania wymogów wyraźnie wynikających z przepisów prawa. $\mathrm{Z}$ drugiej strony spoczywa na tych organach zobowiązanie do podejmowania i rozwijania wzorców działania, które w sposób możliwie najpełniejszy realizować będą wymogi zapisane w przepisie oraz, co istotne, oddziaływać będą w przyszłości na konkretne modele zachowań nie tylko organów władzy, ale i adresatów ich działań. Wynika z tego, że zasada praworządności nie może zostać ograniczona wyłącznie do ujęcia formalnego, to jest działania na podstawie i w granicach prawa pisanego (ius scripta), lecz ujmować winna także spojrzenie materialne, odwołujące się do czegoś więcej aniżeli „proste” działanie zgodnie $\mathrm{z}$ treścią przepisu prawnego ${ }^{2}$.

Nie uda się $\mathrm{w}$ tak skromnej rozprawce zarysowanie choćby napięcia pomiędzy zwolennikami wąsko widzianej zasady praworządności a propagatorami „czytania” prawa w jego „duchu”. Nie jest to zresztą celem tej pracy. Musi więc wystarczyć zasygnalizowanie jedynie tego zagadnienia, dla którego ilustracją może być polemika pomiędzy L.L. Fullerem oraz H.L.A. Hartem³ ${ }^{3}$ W poczuciu odpowiedzialności przed własnym sumieniem, podejmując dalsze uwagi, chciałbym jednak odwołać się do spojrzenia, mającego w mojej ocenie charakter całościowy, a które zakotwiczone jest w preambule do Konstytucji RP. Dla dalszych wywodów przyjmuję dwa założenia, jakie z konieczności zwięzłego wyrażania myśli uznaję za aksjomaty. Uważam zatem najpierw, że ta część Konstytucji ma charakter normatywny na równi z pozostałymi jej przepisami ${ }^{4}$. Potem zaś twierdzę, że właściwe odczytanie przepisów prawa polskiego, a zwłaszcza Konstytucji nie jest możliwe bez podjęcia trudu odnajdywania treści zawartych w preambule ustawy zasadniczej pojęć nieostrych: dobra, prawdy, sprawiedliwości i piękna, będących podstawą prawa w ogólności. Nawet bowiem, gdyby sama Konstytucja nie odwoływała się wyraźnie do owych wartości, to samo prawo - o ile jest godziwe - do tychże odnosić się musi.

Te wstępne uwagi służą podkreśleniu konieczności ciągłego, w okolicznościach zmieniających się wyzwań życia społecznego, odczytywania wartości

${ }^{2}$ W sposób ironiczny, jak się wydaje, odniósł się ostatnio do tego rodzaju ujęcia zasady praworządności M. Filar (Duchem go czy litera, „Palestra” 2013, z. 7-8, s. 250-251), zastrzegając jednak brak możliwości przeprowadzenia szerszych rozważań na ten temat, z uwagi na wąskie ramy swej wypowiedzi.

${ }^{3} \mathrm{Na}$ ten temat por. J. Zajadło, W pięćdziesiąta rocznicę debaty Hart-Fuller, „Państwo i Prawo" 2008 , nr 7, s. 5 i n.

${ }^{4}$ Odmiennie przykładowo R. Stemplowski (op. cit., s. 92) w cytowanej wyżej publikacji, nie rozwijając jednak tego zagadnienia. M. Stefaniuk (A. Dębiński, P. Stanisz, T. Barankiewicz i in. (red.), Preambuła aktu normatywnego a formalizm i antyformalizm $w$ procesie stosowania prawa, [w:] Abiit, non obiit. Księga poświęcona pamięci Księdza Profesora Antoniego Kościa SVD, Lublin 2013, s. 349-350) uznaje wyrażone przeze mnie stanowisko za nieugruntowane w polskiej i zagranicznej doktrynie i orzecznictwie sądowym, zaznaczając jednak, że tożsamy w istocie pogląd wyrażony został w wyroku Trybunału Konstytucyjnego z dnia 16 grudnia 2009 r., Kp 5/08, OTK -A 2009, nr 11, poz. 170. 
tkwiących u fundamentów prawa i państwa prawa, a w konsekwencji służą także odnalezieniu właściwego odniesienia aksjologicznego dla kontroli administracji publicznej w Polsce, sprawowanej przez Naczelny Sąd Administracyjny i wojewódzkie sądy administracyjne. Wartością nadrzędną, moderującą system aksjologiczny odnoszony do sądownictwa administracyjnego winna być przywołana już troska o dobro wspólne. Sędzia w ogóle, a sędzia sądu administracyjnego zwłaszcza, nie powinien zadowalać się rozstrzygnięciami w rozpoznawanych przez niego sprawach o charakterze jedynie formalnie sprawiedliwym, ale winien iść „,W głąb” problemu, poszukując, nawet kosztem pozornej sprzeczności z literą prawa, rozwiązań w pełni adekwatnych do skali i rodzaju wartości leżących u podłoża „konfliktu” pomiędzy państwem i innymi podmiotami publicznymi a obywatelem. Nie może on więc poprzestawać na podjęciu rozstrzygnięcia pozornie poprawnego, bo mającego oparcie w jednoznacznie brzmiącej treści przepisu, ale zarazem niesłusznego z punktu widzenia przeciętnego obywatela. Wcale nie musi tu chodzić o postać „ustawowej formy niesprawiedliwości”, lecz o rozstrzygnięcie dylematu podjęcia orzeczenia „słusznego”, które pozostaje w jakimś stopniu kontrowersyjne względem ,jasnego" przepisus.

\section{Kasacyjny model kontroli sądowoadministracyjnej}

Rozwiązaniem kluczowym dla oblicza polskiego sądownictwa administracyjnego jest przyjęta w przepisach ustawy z dnia 30 sierpnia 2002 r. Prawo o postępowaniu przed sadami administracyjnymi ${ }^{6}$ konstrukcja orzekania kasacyjnego. Rozwiązanie to zasadniczo nawiązywało do modelu ukształtowanego w Drugiej Rzeczypospolitej, wzorowanego na procedurze austriackiej ${ }^{7}$, które zakładało, że wystarczającym do skorygowania wadliwego orzeczenia organu administracji publicznej jest wyeliminowanie tego orzeczenia z obrotu prawnego i ewentualne przekazanie sprawy do ponownego rozpoznania temu organowi wraz ze stosownymi wytycznymi co do kierunku, jaki powinno przyjąć postępowanie administracyjne

${ }^{5} \mathrm{~W}$ polskiej literaturze już dość dawno wyrażony został przez M. Zielińskiego pogląd, który zyskał sobie znaczną przychylność wśród przedstawicieli judykatury, w tym także administracyjnej, iż nie ma przepisu, który nie wymagałby wykładni; por. tenże, Podstawowe zasady wspótczesnej wyktadni prawa, [w:] P. Winczorek (red.), Teoria i praktyka wykładni prawa, Warszawa 2005, s. 201; tenże, Wykładnia prawa. Zasady, reguty, wskazówki, Warszawa 2010, s. 60-61, 314.

${ }^{6}$ Dz. U. z 2012 r. poz. 270 ze zm., w brzmieniu obowiązującym w dniu 10 października 2013 r., dalej: p.p.s.a.

7 D. Malec, Sadownictwo administracyjne, [w:] J. Malec, D. Malec, Historia administracji i myśli administracyjnej, Kraków 2003, s. 239. W. Witkowski (Historia administracji w Polsce 1764-1989, s. 363) powołując się na inną pracę tej autorki, twierdzi natomiast, że ustawa z dnia 3 sierpnia 1922 r. o Najwyższym Trybunale Administracyjnym „była próbą kompromisu między różnymi projektami legislacyjnymi, odwołującymi się do wzorów pruskich bądź francuskich, a realiami nowo powstającego państwa". 
oraz - o ile to konieczne - wraz z uwagami co do należytej wykładni przepisów prawa materialnego. Założeniem ściśle związanym z tym modelem orzekania jest uznanie, że administracji publicznej nie powinien wykonywać sąd administracyjny, który nie jest powołany do tego, a ma jedynie za obowiązek skontrolowanie prawidłowości działania organu administracji ${ }^{8}$. Założenie to, jak wskazuje się w doktrynie, zasadza się na odmiennych celach postępowania administracyjnego i sądowoadministracyjnego. O ile to pierwsze służy konkretyzacji stosunku administracyjnoprawnego na podstawie norm prawa materialnego i w ustalonym stanie faktycznym sprawy, to drugie służy jedynie kontroli tej ,konkretyzacji”, gdyż sąd może orzekać jedynie kasacyjnie 9 . Sąd administracyjny, jak wskazywał J.S. Langrod, „nie ma nigdy administrować, a tylko i jedynie kontrolować”10. Sąd ten nie może brać bezpośredniej odpowiedzialności za załatwienie indywidualnej sprawy administracyjnej. Wskazana odpowiedzialność spoczywa na organie administracyjnym, zaś sąd władny jest jedynie wskazać organowi kroki warunkujące - w ocenie sądu - podjęcie prawidłowego rozstrzygnięcia w sprawie.

Dojmujące wrażenie budzi sposób ujęcia tej kwestii w procedurze sądowoadministracyjnej. Twierdzenie o kasacyjnym modelu orzekania przez sądy administracyjne jest aksjomatem, to jest twierdzeniem przyjmowanym za prawdziwe a priori, bez dowodu. Zasadniczą jego zaletą jest uporządkowanie sposobu myślenia co do reguł dotyczących załatwiania spraw administracyjnych. Wydaje mi się jednak, że twierdzenie to prowadzi rezultatu procesowego, które może być odczytywane przez adresatów działań administracji jako swego rodzaju ,umywania rąk" przez składy orzecznicze sądów administracyjnych zwłaszcza, gdy idzie o rozstrzyganie wątpliwości rodzących się przy rozpoznawaniu spraw złożonych, skomplikowanych, tzw. hard cases. Podzielam pogląd wyrażony w doktrynie, że rozpoznając takie sprawy sędziowie zobowiązani są odnieść się do relacji

8 R. Hauser, Założenia reformy sądownictwa administracyjnego, „Państwo i Prawo” 1999, nr 12, s. 22 nn. Z nowszej literatury np.: A. Krawiec, Autokontrola decyzji administracyjnej, Kraków 2012, s. 118 wraz z powołaną literaturą.

9 Ibidem. Zależność tę B. Adamiak wyraziła w następującej formule: ,prawo procesowe administracyjne nie jest prawem procesowym sądowoadministracyjnym, jak i prawo procesowe sądowoadministracyjne nie jest prawem procesowym administracyjnym”. Taż, Rozgraniczenie regulacji prawa procesowego administracyjnego od regulacji prawa procesowego sadowego, [w:] R. Hauser, A. Wróbel, Z. Niewiadomski (red.), System prawa administracyjnego, t. 4, Prawo procesowe administracyjne, Warszawa 2009, s. 18.

10 J.S. Langrod, Instytucje prawa administracyjnego, Zarys części ogólnej, Reprint, Kraków 2003, s. 345 wraz z powołaną literaturą. Na marginesie powyższych uwag wskazać trzeba, że ten sam autor wskazywał jednak na istotne wady kasacyjnego modelu orzekania przez sądy administracyjne wynikające $\mathrm{z}$ braku możliwości wyegzekwowania wyroku uchylającego decyzję administracyjną. Jako remedium na tę słabość kontroli sądowej nad administracją proponował oparcie się na rozwiązaniach francuskich i niemieckich, w których wyrok sądu administracyjnego stanowi tytuł wykonawczy. Tenże, Kontrola administracji. Studja, Warszawa-Kraków 1929, s. 160-161; cyt. za Z. Kmieciak, Postępowanie administracyjne i sadowoadministracyjne a prawo europejskie, Warszawa 2010, s. 107. 
prawa z moralnością (kontekstu aksjologicznego), niezależnie od przyjmowanej przez nich filozofii prawa ${ }^{11}$. Otóż fakt, że kasując zaskarżoną decyzję sędzia nie bierze na siebie ostatecznej odpowiedzialność za jej treść, lecz robi to organ, który rozstrzyga sprawę administracyjną, rodzić może poczucie zwolnienia się od obowiązku poszukiwania rozwiązania trudniejszego, ale sprawiedliwego materialnie, zamiast łatwiejszego rozstrzygnięcia zgodnego z sprawiedliwością formalnie, to jest zgodnego z zasadą dura lex sed lex.

Nasuwa się więc pytanie, czy po kilkunastu latach od uchwalenia p.p.s.a. i po blisko 10 latach jej stosowania formuła orzekania kasacyjnego może być uznawana za satysfakcjonującą. Odpowiedź na to pytanie poprzedzić trzeba krótkim wstępem historycznym. Kiedy w kwietniu 2009 r. prezydent Rzeczypospolitej Polskiej Lech Kaczyński brał udział w Zgromadzeniu Ogólnym Sędziów Naczelnego Sądu Administracyjnego podsumowując okres obowiązywania nowych przepisów stwierdził, że pomimo swoich wcześniejszych wątpliwości dotyczących przyjętego w Polsce modelu orzekania przez sądy administracyjne, uznaje, iż model ten sprawdził się. Sprawna i rzetelna praca tych sądów pozwala na właściwe korygowanie wszystkich istotnych wadliwości pojawiających się w działalności administracji publicznej ${ }^{12}$. Odmienne stanowisko w tej kwestii zajął natomiast urzędujący obecnie prezydent Rzeczypospolitej Polskiej Bronisław Komorowski. Podczas swego wystąpienia na Zgromadzeniu Ogólnym Sędziów NSA w dniu 16 kwietnia 2013 r. wskazał mianowicie, że formuła orzekania kasacyjnego, pomimo swych zalet, prowadzi do istotnych nieprawidłowości. Nieprawidłowości tych dopatrywał się prezydent w wynikającej z tego rozwiązania nagannej praktyki, określanej mianem „efektu jo-jo”, polegającej na tym, że sprawa wielokrotnie „krąży” między organami a sądami administracyjnymi, podczas gdy obywatel oczekuje na wyrok, który wreszcie skutecznie będzie mógł wyegzekwować ${ }^{13}$. Tego rodzaju nieprawidłowościom nie jest w stanie przeciwdziałać ani NSA ani wojewódzkie sądy administracyjne, gdyż nie mają one uprawnień reformatoryjnych. W związku z tym prezydent zaproponował obecnym sędziom wspólne przygotowanie projektu nowelizacji p.p.s.a., której zadaniem byłoby wprowadzenie ograniczonej możliwości orzekania reformatoryjnego, przy zachowaniu zasadniczo kasacyjnego modelu sądownictwa administracyjnego ${ }^{14}$.

\footnotetext{
11 J. Stelmach, Prawo wobec wartości, [w:] R. Sarkowicz, J. Stelmach, Teoria prawa, Kraków 2001, s. 173,

12 Źródło: http://www.nsa.gov.pl/index.php/pol/NSA/Aktualno\%C5\%9Bci/Wydarzenia,-wizyty,-konferencje/Zgromadzenie-Og\%C3\%B3lne-S\%C4\%99dzi\%C3\%B3w-Naczelnego-S\%C4\%85du-Administracyjnego-z-dnia-27-kwietnia-2009-r. (odczyt 10.10.2013). Nie udało mi się dotrzeć do pełnego tekstu tego wystąpienia. Krótką informację na jego temat przedstawił również P. Florjanowicz-Błachut, Sprawozdanie, „Zeszyty Naukowe Sądownictwa Administracyjnego” 2009, nr 3, s. 18.

13 Por. Z. Kmieciak, op. cit., s. 109.

14 Źródło: http://www.youtube.com/watch?v=xGpWzq225Mc (odczyt 10.10. 2013).
} 
Praktyka potwierdza powyższe wątpliwości. Wiele spośród spraw, dotyczących choćby prawa budowlanego, zwrotu wywłaszczonych nieruchomości czy nawet pomocy społecznej nie kończy orzeczenie sądu pierwszej instancji, ewentualnie poddane kontroli instancyjnej NSA, ale po wielokroć pojawiają się one na wokandach. Taka sytuacja nierzadko wynika nie ze złej woli czy poważnych uchybień organów administracji publicznej lub sądów administracyjnych, lecz ze splotu nieistotnych z pozoru potknięć, jakie powodują dodatkowe komplikacje prawne na etapie rozpoznawania spraw administracyjnych i sądowoadministracyjnych. Większość tych potknięć „prowokują” obecne przepisy. Przykładów takich sytuacji można szukać przynajmniej w trzech obszarach działania sądów administracyjnych, a zwłaszcza wojewódzkich sądów administracyjnych, które rozpoznają większość spraw sądowoadministracyjnych i które - co do zasady - rozpoznają skargi (wyjątek od tej reguły przewiduje art. 188 p.p.s.a.).

W razie ponownego orzekania przez wojewódzki sąd administracyjny w tej samej sprawie już na samym początku pojawia się problem ustalenia właściwego składu dla rozpoznania skargi na decyzję ostateczną. Od kilku bowiem lat, może się wydawać, że w wyniku „nadgorliwości” lub nawet „bezmyślności” ustawodawczej, wprowadzono zakaz orzekania w sprawie przez sędziego, który rozpoznawał sprawę wcześniej. Zakaz ten obowiązuje, pomimo że zapadłe wcześniej prawomocne orzeczenie nie zostało uchylone, a zatem wiąże nie tylko organy administracji publicznej i sąd, ale również wszelkie inne podmioty (art. 170 p.p.s.a.). Zasadnie zwrócono uwagę w orzecznictwie na brak racjonalnego uzasadnienia dla istnienia takiej podstawy wyłączenia sędziego ${ }^{15}$. Przecież sędzia, który orzekał już w określonej sprawie, po ponownym skierowaniu jej na drogę sądową, wprawdzie w zmienionych nieco okolicznościach, bo z „nową” decyzją ostateczną, zna dobrze stan sprawy i to właśnie on najlepiej jest w stanie ocenić zgodność z prawem „nowej” decyzji. Tymczasem ustawodawca uznał takiego sędziego za iudex inhabilis, pomimo że pogląd wyrażony uprzednio przez tego sędziego w prawomocnym wyroku jest wiążący w sprawie ${ }^{16}$.

15 W uzasadnieniu wyroku NSA z dnia 20 kwietnia 2010 r., II OSK 699/09, LEX nr 597785, wskazano, iż „dodana podstawa wyłączenia sędziego (art. 18 § 1 pkt 6a p.p.s.a.) nie ma nic wspólnego z przypadkiem rozstrzygniętym przez Trybunał Konstytucyjny [z dnia 14 października 2008 r., SK 6/07, OTK - A 2008, nr 8, poz. 137 - J.P.]. Przepis ten jest całkowicie nieracjonalny, powinno być bowiem oczywiste, że sędzia biorący uprzednio udział w wydaniu wyroku, czyli sędzia znający materiał procesowy sprawy oraz jej problematykę prawną i najlepiej przygotowany do kontroli wykonania przez organ ocen prawnych i wskazań (art. 153 p.p.s.a.), nie tylko nie powinien podlegać wyłączeniu, ale przeciwnie, wręcz powinien zostać wyznaczony do jej ponownego rozpoznania. Wobec wyraźnego brzmienia tego unormowania pozostaje jedynie, oczekując na jego uchylenie bądź stosowną zmianę, przy jego stosowaniu opierać się na wykładni ścisłej”.

16 Trzeba zauważyć, iż zgodnie z projektem prezydenckim ustawy o zmianie ustawy - Prawo o postępowaniu sądami administracyjnymi (druk sejmowy nr 1633, s. 2; źródło: http://orka. sejm.gov.pl/Druki7ka.nsf/0/D19D22B3A179A839C1257BD400425C1F/\%24File/1633.pdf, s. 2, odczyt: 10.10.2013 r., godz. 15:05) art. $18 \S 1$ pkt 6a P.p.s.a. uzyskać ma nowe brzmienie, 
Druga kwestia także dotyczy związania sądu własną oceną prawną i wskazaniami co do dalszego postępowania, adresowanymi do organu administracyjnego. Kwestia ta na pierwszy rzut oka nie budzi żadnych wątpliwości, jednakże trzeba zwrócić uwagę na problem jaki niejednokrotnie rodzi się w tym zakresie, w sprawach o złożonym stanie faktycznym i prawnym. W sprawach tych sąd rozpoznający sprawę po raz pierwszy i dochodzący do przekonania, że organ administracji naruszył w poważnym zakresie przepisy postępowania, skutkiem czego konieczne jest powtórzenie postępowania wyjaśniającego w istotnej części albo w ogóle przeprowadzenie go od nowa, sąd nierzadko nie jest w stanie wypowiedzieć się co do ewentualnych skutków z zakresu prawa materialnego. Skoro sprawa nie jest dostatecznie wyjaśniona, przedwczesne jest wypowiadanie się sądu na temat naruszenia przepisów prawa materialnego. Twierdzenie to jest uznawane za aksjomat zarówno w orzecznictwie, jak i w doktrynie ${ }^{17}$. Na pierwszy rzut oka jego prawidłowość nie budzi wątpliwości. Konsekwencją jednak takiego ostrożnego podejścia sądu jest choćby to, że przy ponownym rozpoznawaniu sprawy przez wojewódzki sąd administracyjny, sąd ten nie jest związany oceną prawną w zakresie prawa materialnego i formułuje własną, którą dopiero organ administracji, rozpoznając - w razie wydania następnego wyroku uchylającego zaskarżony akt - po raz kolejny, będzie mógł się zapoznać po raz pierwszy.

Trzecie zagadnienie problemowe związane jest z brakiem możliwości reformatoryjnego orzekania $\mathrm{w}$ razie dojścia przez wojewódzki sąd administracyjny do przekonania, że zaskarżona decyzja podlega uchyleniu na podstawie art. 145 $\S 1$ pkt 1 lit. a p.p.s.a., a więc gdy decyzja ta została wydana z naruszeniem przepisów postępowania innych niż przepisy o wznowieniu postępowania administracyjnego, które to naruszenie „mogło mieć istotny wpływ na wynik sprawy”. Zdarza się bowiem, że sąd na podstawie tego przepisu obowiązany jest skasować zaskarżony akt, mimo że - zgodnie z wewnętrznym poczuciem sędziego - sprawa

zgodnie z którym sędzia będzie wyłączony z mocy ustawy tylko w sprawach „,dotyczących skargi na decyzję lub postanowienie rozstrzygające sprawę co do istoty, wydanych w postępowaniu administracyjnym nadzwyczajnym, jeżeli w prowadzonym wcześniej postępowaniu sądowoadministracyjnym dotyczącym kontroli legalności decyzji albo postanowienia, wydanych w postępowaniu administracyjnym zwyczajnym, brał udział w wydaniu wyroku lub postanowienia kończącego postępowanie w sprawie". Tym samym, gdyby wspomniany przepis uzyskał proponowaną treść, oznaczałoby to bardzo racjonalne zawężenie zakresu wyłączenia sędziego, co byłoby zgodne ze stanowiskiem wyrażonym w powołanym wyroku TK z dnia 14 października 2008 r., SK 6/07. Na temat tego wyroku por. także W. Kręcisz, W. Taras, Glosa do wyroku Trybunału Konstytucyjnego z dnia 14 października 2008 r., sygn. akt SK 6/07, „Zeszyty Naukowe Sądownictwa Administracyjnego" 2009, nr 3, s. $205 \mathrm{n}$.

17 Zob. wyrok WSA we Wrocławiu z dnia 31 maja 2013 r., II SA/Wr 172/13, w którym powołano się na wyrok NSA z dnia 10 lutego 1981 r., SA 910/80, ONSA 1981, nr 1, poz. 7 oraz na stanowisko T. Wosia, który uznaje, że „kontrola przestrzegania przez organy administracyjne norm prawa materialnego może być przeprowadzona dopiero w ostatniej kolejności”.--tenże, [w:] T. Woś, H. Knysiak-Molczyk, M. Romańska, Prawo o postępowaniu przed sądami administracyjnymi, Komentarz, Warszawa 2012, s. 758. 
i tak przybierze inny niż oczekiwany przez skarżącego obrót. Tym samym skarżący odniesienie jedynie pozorny sukces $\mathrm{w}$ konfrontacji $\mathrm{z}$ organem, albowiem z przepisów prawa materialnego wynika, że nie ma on szans na „,wygranie” sprawy. W orzecznictwie sądowym, zwłaszcza Naczelnego Sądu Administracyjnego, a także w doktrynie dominuje przekonanie, które oczywiście odnosić trzeba zawsze do okoliczności konkretnej sprawy, że zupełnie wyjątkowo przyjąć można, iż na przykład konieczność wydania decyzji odmownej, zamiast wadliwie wydanej decyzji o umorzeniu postępowania, uzasadnia obowiązek uchylenia tej ostatniej decyzji, choć nie ulega wątpliwości sądu, że skarżący nie spełnia przesłanek materialnoprawnych dla potwierdzenia swojego roszczenia publicznego ${ }^{18}$.

\section{Wątpliwości dotyczące projektowanego art. 145a p.p.s.a.}

Powstaje w związku z tym pytanie, czy dla rozwiązania takich zagadnień obojętny pozostaje ukształtowany model kasacyjny orzekania sądów administracyjnych. Czy ewentualna zmiana przepisów p.p.s.a. jest potrzebna, a jeżeli tak, to w jakim kierunku powinny pójść te zmiany. Pytanie to wydaje się dziś bardzo aktualne, albowiem w dniu 10 lipca 2013 r. prezydent Rzeczypospolitej Polskiej przedstawił Sejmowi projekt ustawy o zmianie ustawy - Prawo o postepowaniu przed sądami administracyjnymi, do którego to projektu głównych założeń należy wprowadzenie możliwości merytorycznego orzekania w sprawach rozpoznawanych przez sądy administracyjne. Zgodnie $\mathrm{z}$ tym założeniem proponowane jest dodanie do aktualnego tekstu ustawy art. 145a, na podstawie którego, zdaniem projektodawców, sąd administracyjny może orzekać co do istoty sprawy ${ }^{19}$. Konstrukcja tego przepisu budzi wiele wątpliwości.

W świetle paragrafu 1 tego artykułu „W przypadku, o którym mowa w art. 145 $\S 1$ pkt 1 lit. a lub pkt 2, jeżeli jest to uzasadnione okolicznościami sprawy, sąd zobowiązuje organ do wydania w określonym terminie decyzji lub postanowienia wskazując sposób załatwienia sprawy lub jej rozstrzygnięcie, chyba że rozstrzygnięcie pozostawiono uznaniu organu".

Przede wszystkim uprawnienie orzecznicze wynikające $\mathrm{z}$ tego przepisu nie daje sądom administracyjnym prawa do orzekania reformatoryjnego, czego domagał się prezydent we wspomnianym wystąpieniu oraz na konieczność wprowadzenia którego wskazywał w uzasadnieniu projektu. Sąd administracyjny nie

${ }_{18}$ B. Adamiak, [w:] J. Borkowski, B. Adamiak, Kodeks postepowania administracyjnego. Komentarz, Warszawa 2011, s. 392; por. przykł. wyrok NSA z dnia 15 lutego 2012 r. II GSK 1520/10, Legalis oraz wyrok WSA w Warszawie z dnia 21 czerwca 2011 r., II SA/Wa 181/11, Legalis.

19 Uzasadnienie projektu ustawy o zmianie ustawy - Prawo o postępowaniu przed sadami administracyjnymi, druk sejmowy nr 1633, s. 2; źródło: http://orka.sejm.gov.pl/Druki7ka.nsf/0/ D19D22B3A179A839C1257BD400425C1F/\%24File/1633.pdf (odczyt 10 .10.2013, s. 2, 17). 
uchyla ani nie zmienia zaskarżonej decyzji lub postanowienia, orzekając o istocie sprawy administracyjnej, lecz nakazuje wydanie organowi określonej decyzji lub postanowienia. Dopiero w przypadku niewydania takiego aktu w zakreślonym przez sąd terminie, strona może wnieść do sądu skargę, na podstawie art. 145a $\S 3$ p.p.s.a., żądając wydania orzeczenia w przedmiocie stwierdzenia istnienia lub nieistnienia uprawnienia lub obowiązku. Różnica pomiędzy tymi rozstrzygnięciami na pozór wydaje się być nieistotna, jednakże z punktu widzenia obywatela, oczekującego już długi czas na zakończenie postępowania w jego sprawie, nie pozostaje bez znaczenia. Wyrok sądu nie kończy bowiem tej sprawy, lecz „,przekazuje” ją po raz kolejny do organu. Taki sposób ukształtowania kompetencji orzeczniczych sądu nie wyklucza sytuacji, gdy organ ponownie nie wyda lub będzie się ociągał z wydaniem kolejnej decyzji. Nie wyklucza to również sytuacji, gdy organ w zakreślonym terminie wyda decyzję, która jakkolwiek zasadniczo zawierać będzie rozstrzygnięcie zgodne z zaprojektowaną przez sąd decyzję, ale w pewnym zakresie nie będzie satysfakcjonowała strony, gdyż będzie sprzeczna z jej wnioskiem. Jeżeli sąd administracyjny nie wypowiedział się dostatecznie precyzyjnie co do tej wątpliwej kwestii we wcześniej wydanym wyroku, to niewątpliwie strona skarżąca nie będzie mogła skutecznie skorzystać z uprawnień przewidzianych $\mathrm{w} \S 2$ i 3 projektowanego przepisu, a sprawa prawdopodobnie wróci do sądu. Przykładowo, w razie zobowiązania do wydania decyzji o ustaleniu warunków zabudowy dla skarżącego organ uczyni to w taki sposób, że uniemożliwiona zostanie zabudowa nieruchomości skarżącego zgodnie z całością jego zamierzenia inwestycyjnego.

Druga wątpliwość dotyczy bardzo ograniczonego zakresu orzekania przez sąd w oparciu o powyższy przepis. Wynika bowiem z niego, że sąd stosowałby ten przepis wyłącznie w razie łącznego spełnienia dwóch przesłanek pozytywnych:

1) naruszenia prawa materialnego mającego wpływ na wynik sprawy, skutkującego uchyleniem aktu (decyzji lub postanowienia) lub takiego uchybienia przepisów prawa, które obowiązuje sąd do stwierdzenia nieważności tego aktu;

2) okoliczności sprawy uzasadniających wydanie orzeczenia „quasi-reformatoryjnego" oraz braku zaistnienia przesłanki negatywnej: „rozstrzygnięcie pozostawiono uznaniu organu".

Oznacza to, w pierwszym rzędzie, że przepis ten nie miałby zastosowania we wszystkich sprawach, w jakich podstawą uchylenia decyzji lub postanowienia jest art. $145 \S 1$ pkt 1 lit. b oraz lit. c p.p.s.a. Wyłączenie tych przypadków spod zakresu zastosowania projektowanego art. 145a $\S 1$ jest niezrozumiałe. Przecież i tak można pozostawić w treści przepisu kwantyfikator ,,jeżeli jest to uzasadnione okolicznościami sprawy", który umożliwiłby sądowi racjonalną ocenę każdego przypadku pod kątem możliwości orzeczenia „quasi-reformatoryjnego”. Przykładowo tylko wskazywałem na niektóre przypadki, w których, pomimo istniejących uchybień formalnych, należałoby stworzyć sądowi możliwość zakończenia sprawy. Sąd uznając, że uchybienie to może mieć wpływ (podkr. moje - J.P.) na wynik 
sprawy ma obowiązek uchylenia aktu, jednakże niewątpliwie skróciłoby postępowania wyposażenie sądu w uprawnienie orzecznicze, o jakim mowa w projektowanym przepisie. Szczególnej rozwagi sądu wymagałoby nadto stwierdzenie, czy w przypadku uchylenia aktu wskutek zajścia podstawy wznowienia postępowania administracyjnego „okoliczności sprawy uzasadniają” takie orzeczenie, ale to już inna kwestia. W mojej ocenie nie można także wykluczyć a limine możliwości zobowiązania organu do wydania określonego rozstrzygnięcia w przypadku tzw. uznania administracyjnego. Należy w tym miejscu zwrócić uwagę, iż orzecznictwo, jak wiadomo, przeszło w zakresie kontroli decyzji uznaniowych istotną ewolucję i nie można wykluczyć, że w jednostkowych przypadkach sąd mógłby w ramach przysługujących mu uprawnień „zakończyć” sprawy w sposób określony w art. $145 \mathrm{a} \S 1$.

Odnosząc się do tej kwestii zwrócić należy uwagę na słuszne zastrzeżenia podniesione $\mathrm{w}$ jednej ze zgłoszonych do projektu opinii, dotyczące nietrafności skonstruowania przesłanki wydania powyższego „quasi-reformatoryjnego” orzeczenia w postaci wystąpienia określonych „okoliczności sprawy”. Trafnie podkreślono bowiem, że w każdym przypadku wydania wyroku na podstawie art. 145 $\S 1$ pkt 1 lit. a albo art. $145 \S 1$ pkt 2 p.p.s.a. należałoby rozważyć umożliwienie sądowi zakreślenia terminu na załatwienie przez organ tej sprawy ${ }^{20}$.

Trzecia uwaga dotyczy użycia w projektowanym przepisie funktora alternatywy łącznej „lub”. W logice formalnej, a w ślad za nią w logice prawniczej oraz w języku prawnym i prawniczym, przyjmuje się, że zdanie zbudowane ze zdań podrzędnie złożonych połączonych tym funktorem prawdziwe zarówno wtedy, gdy spełniona została przesłanka wynikając z jednego ze zdań, kilku z tych zdań lub wszystkich zdań podrzędnie złożonych. Oznacza to, iż w świetle proponowanego brzmienia art. $145 \mathrm{a} \S 1$ p.p.s.a. możliwe jest wydanie przez sąd zobowiązanie organu do wydania decyzji ze wskazaniem ,sposobu załatwienia sprawy” oraz - jednocześnie - ze wskazaniem „rozstrzygnięcia sprawy”. Tymczasem wydaje się, że projektodawcy chodziło o coś innego, mianowicie o to, by w jednej sprawie sądowoadministracyjnej sąd mógł wydać tylko jedno z tych rozstrzygnięć. Można sobie jednak teoretycznie wyobrazić sytuację, że sąd na podstawie art. 111 $\S 1$ p.p.s.a. albo na podstawie art. $111 \S 2$ p.p.s.a. połączył dwie lub więcej spraw do wspólnego rozpoznania i rozstrzygnięcia, i doszedł do przekonania, że w jednej z tych spraw należy zobowiązać organ do wydania aktu ze wskazaniem ,sposobu załatwienia sprawy" a w pozostałych - do wydania aktu ze wskazaniem właściwego - zdaniem sądu - rozstrzygnięcia.

Istotne wątpliwości budzi projektowany przepis także w części wskazującej na treść potencjalnego orzeczenia sądu. rozróżnienia w przepisie „sposobu załatwienia sprawy” oraz „rozstrzygnięcia sprawy”. Zakładając racjonalność ustawo-

\footnotetext{
20 Opinia Prokuratorii Generalnej Skarbu Państwa do projektu ustawy o zmianie ustawy - Prawo o postępowaniu przed sądami..., druk sejmowy nr 1633, uwaga 3.
} 
dawcy przyjmuje się powszechnie, że w przypadku, gdy posługuje się on różnymi pojęciami w tej samej ustawie, to za każdym razem ma na myśli coś innego. Poszukując wyjaśnienia znaczenia określenia „sposób załatwienia sprawy” można by dojść do przekonania, że chodzi tu jedynie o wiążące określenie przez sąd administracyjny sekwencji czynności procesowych, które winien podjąć organ administracji w toku ponownego rozpoznania sprawy. Takie rozwiązanie nie jest jednak możliwe, albowiem istniejący przepis art. 153 p.p.s.a. wyraźnie wprowadza już taką możliwość, skoro wynika z niego, że sąd rozpoznający sprawę oraz organ związany jest zawartą $\mathrm{w}$ wyroku oceną prawną $\mathrm{i}$,wskazaniami co do dalszego postępowania'. Owe wskazania zaś to nic innego jak wiążące wytyczne sądu skierowane do organu administracji dotyczące działań, jakie należy podjąć rozstrzygając sprawę. Kwestię tę zdają się zauważać autorzy wspomnianej wyżej opinii, kiedy twierdzą, że „wskazanie sposobu załatwienia sprawy” powinno być zawsze elementem wyroku uchylającego akt (decyzję, postanowienie) lub stwierdzającego jego nieważność ${ }^{1}$. Otóż właśnie art. 153 p.p.s.a. taką możliwość daje sądowi. $Z$ tych względów przepis art. 145a p.p.s.a. w opisanej części w żadnym razie nie może być uznany za superfluum ustawowe, gdyż jasno wynika z uzasadnienia projektu ustawy nowelizującej p.p.s.a., że chodzi w nim o wprowadzenie nowej instytucji procesowej służącej orzekaniu co do istoty sprawy przez sąd.

Trudno również uznać, że wskazując „sposób załatwienia sprawy” sąd byłby władny zobowiązać organ administracji do wydania orzeczenia nie załatwiającego sprawy merytorycznie, to jest rozstrzygnięć mających charakter procesowy, takich jak postanowienie w przedmiocie zawieszenia postępowania, stwierdzenia niedopuszczalności odwołania, stwierdzenia uchybienia terminu do wniesienia odwołania czy - pomijając w tym miejscu spór co do ewentualnego charakteru orzeczenia co do istoty sprawy - decyzji o umorzeniu postępowania. Należy mieć bowiem na względzie, że powodem do zobowiązania do wydania takich rozstrzygnięć zasadniczo mogłoby być wyłącznie naruszenie przepisów postępowania, które co najmniej „mogło mieć” istotny wpływ na wynik sprawy, a więc wówczas, gdy organ zachodziłaby przesłanka do uchylenia zaskarżonej decyzji lub postanowienia na podstawie art. $145 \S 1$ pkt 1 lit. c p.p.s.a. Projektowany przepis wyłącza zaś w sposób zdecydowany taką możliwość, gdyż nie pozwala na wydanie orzeczenia „quasi-reformatoryjnego" w razie konieczności zastosowania powołanego przepisu. Takie orzeczenie może bowiem zapaść tylko w przypadku wydania wyroku Sądu na podstawie art. $145 \S 1$ pkt 1 lit. a albo art. $145 \S 1$ pkt 2 p.p.s.a.

Cóż więc oznacza „wskazanie sposobu załatwienia sprawy”, skoro nie jest ono „wskazaniem rozstrzygnięcia sprawy” ani „wskazaniem co do dalszego postępowania”. Moim zdaniem „rozstrzygnięcie sprawy” to nic innego jak określony „sposób rozstrzygnięcia sprawy”. Wydaje się więc, iż dla uniknięcia wątpliwości interpretacyjnych najlepszym rozwiązaniem byłaby rezygnacja $z$ wprowadzenia omawianej części projektowanego przepisu. Brak tego zwrotu ustawowego nie

\footnotetext{
21 Ibidem.
} 
uniemożliwi sądowi zawarcia w uzasadnieniu wyroku wiążących wytycznych dla organu co do sposobu procedowania w sprawie, zaś wynikająca z projektowanego art. 145a § 1 możliwość zobowiązania organu do określonego rozstrzygnięcia sprawy nie zostanie z tej przyczyny uszczuplona.

Trudno również nie dostrzec pewnych nieścisłości i niedociągnięć, jakie pojawiły się w projektowanych paragrafach 2 i 3 omawianego artykułu.

W świetle art. 145a $\S 2$ p.p.s.a.

[...] o wydaniu decyzji lub postanowienia, o których mowa w $\S 1$, właściwy organ zawiadamia sąd w terminie siedmiu dni od dnia ich wydania. W przypadku niezawiadomienia sądu, może on orzec o wymierzeniu organowi grzywny w wysokości, o której mowa w art. $154 \S 6$. Postanowienie może być wydane na posiedzeniu niejawnym. Stosownie zaś do paragrafu 3 powyższego artykułu „w przypadku niewydania decyzji lub postanowienia, o których mowa w $\S 1$, w określonym przez sąd terminie, strona może wnieść skargę, żądając wydania orzeczenia stwierdzającego istnienie lub nieistnienie uprawnienia lub obowiązku. Sąd wyda orzeczenie w tym przedmiocie, jeżeli pozwalają na to okoliczności sprawy. W wyniku rozpoznania skargi sąd stwierdza, czy niewydanie decyzji lub postanowienia miało miejsce z rażącym naruszeniem prawa i może ponadto z urzędu albo na wniosek strony wymierzyć organowi grzywnę w wysokości, o której mowa w art. 154 § 6 lub przyznać od organu na rzecz skarżącego sumę pieniężną w wysokości określonej w art. 154 § 7.

Pierwsza wątpliwość dotyczy podmiotu legitymowanego do żądania podjęcia przez sąd orzeczeń opisanych w obu powyższych przepisach.

Paragraf 2 nie zawiera informacji na ten temat, gdyż wskazuje jedynie, że w razie nieskierowania przez organ do sądu zawiadomienia o wydaniu aktu żądanego przez sąd we wcześniej zapadłym wyroku, „sąd może orzec” o nałożeniu grzywny. Brak wskazania podmiotu, który może domagać się wymierzenia tej grzywny oznacza, iż inicjatywa podjęcia przez sąd stosownego orzeczenia w tym przedmiocie może pochodzić wyłącznie od sądu, czyli z urzędu. Jest to rozwiązanie niezrozumiałe, albowiem nie ulega wątpliwości, że to skarżący, a nie sąd zainteresowany jest szybkim załatwieniem sprawy przez organ administracji. Dlaczego więc projektodawca uniemożliwia mu złożenie wniosku o zastosowanie tego środka dyscyplinującego organ, nie wiadomo.

W paragrafie 3, odmiennie, znajdujemy natomiast wskazanie, kto jest uprawniony do złożenia środków prawnych w nim określonych. Treść jednak tego wskazania budzi daleko idące wątpliwości. Czytając ten przepis od końca należy zauważyć, że z mocy tej regulacji sąd władny jest do zasądzenia od organu sumy pieniężnej, a więc w istocie odszkodowania, „na rzecz skarżącego”. Sąd może również wymierzyć organowi grzywnę. Orzekając zarówno w przedmiocie odszkodowania, jak i grzywny (w przepisie posłużono się funktorem alternatywy łącznej „lub”), sąd działa „z urzędu albo ${ }^{22}$ na wniosek strony”. Co to oznacza, czyli kto może żądać wymierzenia tej grzywny? Skarżący oczywiście tak,

${ }^{22} \mathrm{Na}$ marginesie należy zauważyć, iż projektodawca posłużył się w tym miejscu w sposób zamierzony funktorem alternatywy rozłącznej ,albo”, co wynika z oczywistego faktu, że postępowanie nie może zarazem toczyć się z urzędu i na wniosek uprawnionego podmiotu. 
ale oprócz niego: uczestnicy postępowania (nawet, gdy mieli oni w tej sprawie sporne ze skarżącym interesy), w tym również organizacje społeczne, o ile brały udział w postępowaniu sądowoadministracyjnym. Ponadto, i tu największe zaskoczenie budzi propozycja projektu, sam organ administracji (podkreśl. moje - J.P.), od którego może zostać zasądzone odszkodowanie i na który może zostać nałożona grzywna. Skąd to wynika? Z tego, że stronami w postępowaniu sądowoadministracyjnym są skarżący oraz organ, którego działanie, bezczynność lub przewlekle prowadzenie postępowania jest przedmiotem skargi (art. 32) oraz z faktu, że ustawa nakazuje uznanie za stronę, oprócz wskazanych podmiotów, także uczestników postępowania (art. 12).

W powołanym par. 3 art. 145a wprowadza się więc rozwiązanie absurdalne, albowiem umożliwia organowi administracji, który nie dochował obowiązków określonych w paragrafie 1, na żądanie od sądu zastosowania wobec niego środków dyscyplinujących określonych w pierwszym z tych przepisów.

Po drugie nie jest jasna relacja, jaka zachodzi pomiędzy powyższymi przepisami. Paragraf 2 dotyczy sytuacji ,niezawiadomienia sądu” przez organ o wydaniu decyzji lub postanowienia w terminie siedmiu dni od dnia ich wydania. Trudno rozstrzygnąć jednoznacznie, czy przepis ten dotyczy tylko przypadku, w którym organ wydał powyższy akt w zakreślonym przez sąd terminie, a nie dochował obowiązku określonego w zdaniu pierwszym tego paragrafu, czy obejmuje również niezawiadomienie sądu o wydaniu aktu, wynikające $\mathrm{z}$ faktu niepodjęcia tego rozstrzygnięcia. O ile uznać, że zakres powyższego przepisu jest szerszy, gdyż obejmuje obie te sytuacje, to, jak się wydaje, należałoby uznać, że zakresy unormowania obu przepisów częściowo pokrywają się. Racjonalnym rozwiązaniem tej kwestii zdaje się przyjęcie węższego zakresu unormowania. W takim przypadku dałoby się, choćby częściowo, uzasadnić wskazaną wyżej różnicę zachodzącą pomiędzy podmiotami legitymowanymi do zastosowania środków dyscyplinująco-represyjnych na podstawie obydwu omawianych paragrafów artykułu 145a p.p.s.a.

Po trzecie, zastanawia, z jakich powodów zróżnicowany został sposób orzekania sądu na podstawie wskazanych przepisów. Zgodnie z paragrafem 2 sąd może rozstrzygać na posiedzeniu niejawnym, a w myśl paragrafu 3 wyłączona została taka możliwość. Zasadą jest, że posiedzenia sądowe są jawne, a sąd orzekający rozpoznaje sprawy na rozprawie, chyba że przepis szczególny stanowi inaczej, nawet jednak wtedy sąd może sprawę skierować na posiedzenie jawne i wyznaczyć rozprawę (art. $90 § 1$ i $§ 2$ p.p.s.a.). Oznacza to, że o grzywnie, o jakiej mowa $\mathrm{w} \S 2$, sąd może orzec zarówno na posiedzeniu niejawnym, jak i na rozprawie, zaś w trybie $\S 3$ może orzekać jedynie na rozprawie. Trudno się zgodzić z powyższym rozwiązaniem, dla nikogo bowiem nie pozostaje spornym, że zasadniczym celem obu opisanych regulacji jest błyskawiczne zakończenie takiej sprawy, tak, by pozwolić uzyskać przez skarżącego oczekiwane przez niego rozstrzygnięcie. Dodatkowo przepisy par. 3 pozwalają na wydanie sądowi orzeczenia w przedmiocie istnienia lub nieistnienia uprawnienia lub obowiązku, ,jeżeli pozwalają na to okoliczności sprawy”. Zakłada więc ten przepis możliwość wydania tego 
orzeczenia w istocie wówczas, gdy - posługując się innym zwrotem - „stan faktyczny i prawny sprawy nie budzi uzasadnionych wątpliwości”. Ten ostatni zwrot zbliża się do określonej w art. $55 \S 2$ p.p.s.a. przesłanki rozpoznania skargi, pomimo nieprzesłania przez organ skargi, a także odpowiedzi na skargę i akt sprawy. W tym zaś ostatnim przypadku, stosownie do art. $121 \mathrm{w}$ zw. z art. 120 p.p.s.a., sąd może również orzec $\mathrm{w}$ trybie uproszczonym na posiedzeniu niejawnym. Taka możliwość w odniesieniu do skargi z art. 145a $\S 3$ wydaje się być jedynie iluzoryczna. Może być oczywiście tak, że skarżący zwróciłby się do sądu, w trybie art. 119 pkt 1 p.p.s.a., $\mathrm{z}$ wnioskiem o rozpoznanie sprawy $\mathrm{w}$ trybie uproszczonym $\mathrm{i}$ wówczas skarga oraz wnioski określone $\mathrm{w}$ art. $145 \mathrm{a} \S 3$ zostałyby rozstrzygnięte na posiedzeniu niejawnym (art. 120 p.p.s.a.), lecz łatwo wyobrazić, że w większości takich przypadków organy administracji byłyby zainteresowane zgłoszeniem w tym zakresie sprzeciwu, skoro na rozprawie - w przeciwieństwie do rozpoznania sprawy na posiedzeniu niejawnym - miałby możliwość pełnego przedstawienia swoich racji, tłumacząc się dodatkowo z popełnionych przezeń uchybień.

Ponadto, co zostało dostrzeżone przez jeden z podmiotów opiniujących projekt, przepis par. 3 jest wadliwy w zakresie, w jakim wskazuje sposób ustalania wysokości odszkodowania zasądzanego na rzecz skarżącego od organu. Istotnie bowiem, wbrew twierdzeniom zawartym w uzasadnieniu projektu, nie można uznać, że przepis wprowadza „możliwość zasądzenia przez sąd od organu na rzecz skarżącego sumy pieniężnej w wysokości od 1000 zł do 10000 złotych". Powołany przepis nie daje takiej możliwości sądowi. Poprzez odesłanie do art. $154 \S 7$ p.p.s.a. sąd może przyznać skarżącemu od organu sumę pieniężną nieprzekraczającą „,1/2 wymierzonej grzywny”. Maksymalna wysokość wymierzonej grzywny może wynieść dziesięciokrotność przeciętnego wynagrodzenia miesięcznego w gospodarce narodowej w roku poprzednim, ogłaszanego przez prezesa Głównego Urzędu Statystycznego. W praktyce oznacza to więc, że sąd może nałożyć grzywnę do kwoty około 36000 złotych $^{23}$. Połowa tej grzywny może zatem przekraczać kwotę 10000 złotych. Zasadnie zwrócono również uwagę, że w tym przepisie nie wskazano kryterium obliczenia powyższego odszkodowania $\mathrm{w}$ razie niewymierzenia organowi grzywny na podstawie tego samego przepisu. Paragraf 3 artykułu 145a w związku z art. 154 § 7 p.p.s.a. pozwala bowiem sądowi na ustalenie wysokości odszkodowania wyłącznie w razie nałożenia na organ grzywny, gdyż - jak wskazano wyżej - sąd może przyznać skarżącemu od organu sumę pieniężną nieprzekraczającą połowy wymierzonej (podkreśl. moje - J.P.) grzywny. Jednocześnie zaś wskutek użycia spójnika „lub” w art. 145a § 3 p.p.s.a., należy uznać, że przepis ten umożliwia tylko zasądzenie odszkodowania bez jednoczesnego orzekania o nałożeniu grzywny ${ }^{24}$.

${ }^{23}$ W myśl obwieszczenia Prezesa GUS z dnia11 lutego 2013 r. w sprawie przeciętnego wynagrodzenia miesięcznego w gospodarce narodowej w 2012 r. i w drugim półroczu 2012 r. („Monitor Polski” z 2013 r., poz. 89) w 2012 r. przeciętne wynagrodzenie miesięczne wynosiło 3 521,67 zł.

${ }^{24}$ Pismo Prokurata Generalnego z dnia 22 sierpnia 2013 r., druk sejmowy nr 1633, s. 5-6. 


\section{Projektowany przepis art. $145 \S 3$ p.p.s.a.}

Zwrócić należy także uwagę, że oprócz dodania wskazanego wyżej artykułu projekt przewiduje rozszerzenie art. 145 p.p.s.a. o nowy par. 3 w brzmieniu: „W przypadku, o którym mowa w par. 1 pkt 1 i 2, sąd, stwierdzając podstawę do umorzenia postępowania administracyjnego, umarza jednocześnie to postępowanie". Dodanie tego przepisu pozwoli sądowi na zakończenie sprawy administracyjnej, a nie tylko sprawy sądowoadministracyjnej, bez konieczności przekazywania sprawy do ponownego rozpoznawania przez organ administracyjny ${ }^{25}$.

W tym przypadku nie podlega wątpliwości, że projektowana zmiana pozwoli na odczuwalne zwiększenie skuteczności i sprawności kontroli sądowej, gdyż stanowi przejaw ograniczonej kompetencji sądu do wydania rozstrzygnięć zastępujących akt administracyjny. Przede wszystkim bowiem proponowany nowy par. 3 artykułu 145 p.p.s.a., odmiennie aniżeli przedstawiony powyżej art. 145a p.p.s.a., daje sądowi realną możliwość reformatoryjnego rozstrzygnięcia sprawy. Trzeba na to zwrócić szczególną uwagę, gdyż projektodawcy, jak się wydaje, opierają się na założeniu, że w świetle art. $184 \S 1$ zd. 1 Konstytucji nie jest możliwe „przejmowanie” przez sądy administracyjne władczego rozstrzygania sprawy administracyjnej, gdyż ta kompetencja należy wyłącznie do organów administracji publicznej. Wychodzą oni bowiem z założenia, że ,rolą sądu administracyjnego sprawującego wymiar sprawiedliwości jest badanie (korygowanie) tych [to jest władczych J.P.] działań lub zaniechań" organów administracji publicznej. Z tego właśnie względu autorzy projektu uznają, że projektowany art. 145a p.p.s.a. nie narusza zasady ustrojowej podziału władz zawartej w art. 10 ust. 1 Konstytucji oraz jej zapisów dotyczących zakresu orzekania sądów administracyjnych, to jest kontroli działalności administracji publicznej ${ }^{26}$.

Powyższy pogląd prowadzi do sprzeczności, gdy chodzi ratio legis proponowanych zmian, albowiem uznając wynikające $\mathrm{z}$ niego założenie co do dopuszczalnego zakresu kognicji sądów administracyjnych, należałoby uznać, że projektowany art. $145 \S 3$ p.p.s.a. byłby sprzeczny (podkreśl. moje - J.P.) z powołanymi wyżej wzorcami konstytucyjnymi. Powołane przepisy Konstytucji nie zawierają bowiem upoważnienia dla ustawodawcy dla odmiennego uregulowania tej kwestii. Nie wynika z nich możliwość stosowania żadnych wyjątków. Powyższe, jak się wydaje, dowodzi zasadności tezy odmiennej, iż przepisy Konstytucji nie wykluczają, że kontrola działalności administracji publicznej nie wyklucza możliwości rozstrzygania „w miejsce” organów tej administracji indywidualnych spraw administracyjnych.

${ }_{25}$ R. Hauser, Wstępne założenia nowelizacji ustawy - Prawo o postępowaniu przed sq̨dami administracyjnymi, „Państwo i Prawo” 2013, nr 2, s. 19-20.

${ }^{26}$ R. Hauser, op. cit., s. 22-23. 


\section{Uwagi końcowe}

Proponowana zmiana legislacyjna, jakkolwiek wypływa z prawidłowego założenia co do konieczności przełamania absolutyzacji zasady kasacyjnego orzekania przez sądy administracyjne w Polsce budzi zastrzeżenia. Zastanawia przede wszystkim zawarta w uzasadnieniu projektu ocena mechanizmu orzeczniczego wprowadzonego $\mathrm{w}$ proponowanym przepisie. Zdaniem projektodawcy ,zmiana ta [to jest dodanie art. 145a p.p.s.a.] przyznaje w konsekwencji sądowi administracyjnemu prawo do wydania merytorycznego rozstrzygnięcia, a nie tylko ograniczenia się do uchylenia zaskarżonego aktu"27. Merytoryczne rozstrzygnięcie nadal zapadać będzie zasadniczo wyłącznie w postępowaniu administracyjnym, zaś sąd kontrolujący zgodność z prawem zaskarżonej decyzji lub postanowienia będzie tylko mógł mięć silniejszy wpływ na jego treść. Wadliwe jest również stwierdzenie, że opisane w art. $145 \mathrm{a} \S 1$ p.p.s.a. ,uprawnienie sądu będzie wyłączone jedynie, gdy przepisy pozostawiają rozstrzygnięcie uznaniu organu". Niewątpliwie bowiem, jak wskazano wyżej, w projekcie ustawy wprowadza się dwa inne wyłączenia dotyczące charakteru naruszenia prawa przez organ administracji oraz bardzo ogólne, a więc również bardzo pojemne, dotyczące charakteru „okoliczności sprawy uzasadniających" podjęcie rozstrzygnięcia na podstawie omawianego przepisu. Zbyt daleko idące jest twierdzenie autorów uzasadnienia projektu, że powyższy przepis ,zapobiega także przypadkom niewykonania wytycznych sądu”. Jakkolwiek strona uzyskała „nowe” uprawnienia opisane w art. 145a § 2 i $\S 3$ p.p.s.a., to $\mathrm{w}$ istocie mają one bardzo zbliżony charakter do przysługującego - z mocy art. $154 \S 1$ p.p.s.a. - prawa do złożenia skargi o wymierzenie grzywny z powodu niewykonania wyroku uwzględniającego skargę na bezczynność lub przewlekłe prowadzenie postępowania oraz z powodu bezczynności organu lub przewlekłego prowadzenia postępowania po wyroku uchylającym lub stwierdzającym nieważność aktu lub czynności. Z pewnością prawidłowym rozwiązaniem jest natomiast powierzenie sądom kompetencji reformatoryjnej, określonej w art. $145 \S 3$ p.p.s.a.

Czy zatem przyjęcie proponowanych zmian przyniesie efekty oczekiwane przez Prezydenta Rzeczypospolitej Polskiej, to jest doprowadzi do poprawy sprawności postępowania oraz szybszego uzyskania merytorycznego rozstrzygnięcia sprawy? Wydaje się, że pomimo opisanych wyżej mankamentów, projektowane zmiany idą zasadniczo $\mathrm{w}$ dobrym kierunku, choć warto byłoby jednak zastanowić się głębiej przynajmniej nad przyznaniem sądom szerszych uprawnień „quasi-reformatoryjnych”, jeżeli nie uznaje się za zasadne wyposażenie sądów administracyjnych w kompetencję do orzekania merytorycznego. Wskazać również należy, że projektowana nowelizacja zdaje się mieć charakter niezwykle zachowawczy na tle podejmowanych w ostatnich latach w Europie

27 Uzasadnienie projektu ustawy..., s. 2, 17. 
zmianach legislacyjnych dotyczących kompetencji orzeczniczych sądów administracyjnych ${ }^{28}$. Przykładem takich zmian najciekawszym, choćby z racji na wpływ pierwotnych założeń ustawowych, jest z pewnością reforma sądownictwa administracyjnego w Austrii, która oznaczała zerwanie z tradycyjnym modelem kontroli administracji publicznej oraz wprowadzenie rewolucyjnych zmian ustrojowych i procesowych. Zgodnie ze znowelizowanym art. 130 ust. 4 Federalnej Ustawy Konstytucyjnej obowiązkiem sądów administracyjnych jest wydawanie rozstrzygnięć merytorycznych $\mathrm{w}$ sprawach karno-administracyjnych, zaś w innych sprawach - wówczas gdy „stan faktyczny sprawy nie budzi wątpliwości albo samodzielne ustalanie stanu faktycznego sprawy przez sąd administracyjny jest uzasadnione (podkreśl. moje - J.P.) względami szybkości bądź związane ze znaczną oszczędnością kosztów"29. Reforma ta, co należy podkreślić, poprzedzona została opracowaniem dwóch projektów zmian legislacyjnych w 2007 r. oraz w $2010 \mathrm{r}^{30}$ Wydaje się, że taka przemyślana istotna reforma uprawnień orzeczniczych sądów administracyjnych potrzebna byłaby także w Polsce. Z tych względów polski ustawodawca kształtując zmiany w p.p.s.a., które w przeciwieństwie do austriackich nie wymagają korekt o charakterze ustrojowym, powinien mieć na względzie potrzebę przyznania tym sądom realnego, a nie tylko „dekoracyjnego", uprawnienia do merytorycznego rozstrzygania spraw administracyjnych w szerokim zakresie. Uprawnienie to, jak zasadnie zwraca się uwagę w doktrynie, powinno być powiązane z rozważeniem reformy modelu jurysdykcyjnego postępowania administracyjnego, polegającej na ograniczeniu go do jednej instancji orzeczniczej, tak jak to uczyniono w Austrii ${ }^{31}$.

Konieczne jest więc dziś przemyślenie na nowo paradygmatu kasacyjnego modelu orzeczniczego sądów administracyjnych w Polsce. Nie do utrzymania jest bowiem teza, iż ,przejęcie przez sąd administracyjny kompetencji organu administracji do końcowego załatwienia [sprawy administracyjnej - J.P.] stanowiłoby wykroczenie poza konstytucyjnie określone granice kontroli administracji publicznej ${ }^{32}$.

${ }^{28}$ Na temat działań podejmowanych w tym kierunku w Europie por. Z. Kmieciak, Efektywność sądowej kontroli administracji publicznej, „Państwo i Prawo” 2010, nr 11, s. 21-34 oraz A. Skoczylas, Modele uprawnień orzeczniczych sądów administracyjnych w Europie, „Państwo i Prawo” 2012, nr 10, s. 21-32.

29 Austria - reforma sądownictwa administracyjnego. Wybór przepisów znowelizowanych 51. ustawa federalna Verwaltungsgerichtsbarkeits-Novelle 2012, thum. i oprac. Z. Kmieciak, P. Florjanowicz-Błachut, „Zeszyty Naukowe Sądownictwa Administracyjnego” 2013, nr 4, s. 189, 192.

30 A. Krawczyk, Reforma sadownictwa administracyjnego w Austrii, „Państwo i Prawo” 2013, nr 4, s. 38 .

31 Ibidem, s. 46. Autorka ta uważa, że dokonana w Austrii „reforma sądownictwa administracyjnego i związana z tym zmiana modelu postępowania administracyjnego stanowią przejaw naturalnej ewolucji wyrosłych z tych samych tradycji kasacyjnych systemów sądownictwa administracyjnego".

32 R. Hauser, op. cit., s. 25. 